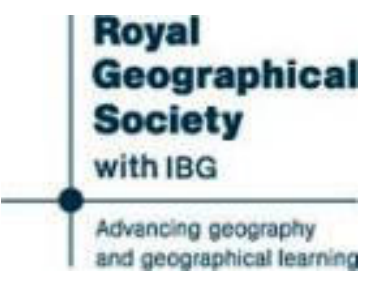

A Journey from Chesterfield Inlet to Great Slave Lake, 1898-9

Author(s): David T. Hanbury

Source: The Geographical Journal, Vol. 16, No. 1 (Jul., 1900), pp. 63-77

Published by: The Royal Geographical Society (with the Institute of British Geographers)

Stable URL: http://www.jstor.org/stable/1774300

Accessed: 11-03-2015 20:15 UTC

Your use of the JSTOR archive indicates your acceptance of the Terms \& Conditions of Use, available at http://www.jstor.org/page/info/about/policies/terms.jsp

JSTOR is a not-for-profit service that helps scholars, researchers, and students discover, use, and build upon a wide range of content in a trusted digital archive. We use information technology and tools to increase productivity and facilitate new forms of scholarship. For more information about JSTOR, please contact support@jstor.org.

The Royal Geographical Society (with the Institute of British Geographers) is collaborating with JSTOR to digitize, preserve and extend access to The Geographical Journal. 


\title{
A JOURNEY FROM CHESTERFIELD INLET TO GREAT SLAVE LAKE, 1898-9.*
}

\author{
By DAVID T. HANBURY.
}

With the object in view of crossing and exploring that portion of the Barren Northland of Canada which lies between the head of Chesterfield inlet and Great Slave lake, I left Winnipeg by first open water in the early part of May, 1898. The starting-point for this journey was Fort Churchill, on the west coast of Hudson bay, which was reached on July 6, after an easy canoe journey viâ Norway House, Oxford House, and York Factory. To my disgust, and very much to my surprise, I now learnt that it would not be possible to start north by open water until July 20, the earliest date, in average years, when navigation opens on Hudson bay. Two Cree lads, whom I had engaged at Oxford House to accompany me on the journey, and who had gone through the farce of signing contracts to remain in my service faithfully for the period of one year, now pleaded sickness as an excuse for wishing to return to their homes. The whole way along, I knew very well that by every one we met they had been dissuaded from undertaking the journey. Pictures of hordes of cannibal Eskimo devouring raw human flesh had been placed vividly before their imaginations by other Indians, one and all of whom have a dread of approaching "Husky" or Eskimo land. The lads were finally so overcome with horror and äismay at the mere prospect of getting anywhere near such terrible savages as the Eskimo, that I fancy they really were sick from sheer fright. Anyway, men in this condition would be of little service to me. The contract was off, and they returned in a hurry to their people at Oxford House. The Hudson Bay trading boat was to start north for Marble island about July 20. An average trip would take ten days. This would have landed me within 60 miles of the entrance to Chesterfield inlet about August 1-too late in the season, in my judgment, to commence a long journey into an altogether unexplored country. After due consideration, I decided to postpone the journey, and content myself with taking up the canoe, and leaving it in cache near Marble island till the following spring, for I intended to leave Churchill in the spring, and haul up as far as possible on the ice with dogs and sleighs.

The short summer was passed in taking a run up in the Company's trading boat, caching the canoe near Marble island, and in learning as nuch about the Eskimo-their language and the country to the north -as my time permitted. At the same time I managed to secure from them two trains of fine Eskimo dogs, as it now became necessary for me to take the winter trip to Winnipeg in order to refit and complete my outfit. Before leaving, arrangements were marle for Eskimo (or

\footnotetext{
* Map, p. 140.
} 
Huskies, as I shall in future call them) to meet me at Churchill in the following spring. Two sleighs were also ordered to be made, and other outfit got ready by the time I expected to be back, and on September 5 I bade farewell to Churchill for the winter, no one, I knew very well, expecting to see me return. That concerned me not at all, so long as they got everything in readiness for the projected journey. From Churchill to York the distance is 180 miles, very much more easily accomplished by land than by water.

A delay of six weeks occurred at York, waiting for the "freeze-up," during which time, as soon as the snow fell, I broke in my dogs--several of them never having been hitched up in harness before. On November 8 Hayes river was frozen solid, and as a large amount of snow had fallen, by the advice of my guide, a start was made for Oxford House en route to Winnipeg. Travelling in the early winter on the first snows is never good. However, Winnipeg was reached in about a month, delays having been made at Oxford House and Norway House in order to rest the dogs. The distance from York Factory to Winnipeg is something under 800 miles. The latter part of December, January, and most of February was passed in civilization. A fresh outfit, ordered from England, had duly arrived, and was awaiting me, and two reliable Red river half-breeds were engaged for the journey.

Shortly before my departure, when everything was in readiness, I happened to be one of the unfortunate guests at the Manitoba hotel, which was completely destroyed by fire one night in the early part of February. I was fortunate enough, however, to save my instruments, cameras, rifles, guns, etc.-in fact, everything which was necessary for the trip, and only my clothes went up in smoke.

On February 26 a final start was made from Selkirk. Horses and sleigh were used as far as Berens river (about halfway up Lake Winnipeg), where my dogs and drivers met me. A few days' delay at Norway House, Oxford House, and a week at York Factory to rest my dogs, and I appeared once more on the scene at Churchill-the first week in April. The spring was luckily a very late one, so there was no immediate necessity for hurrying away from Churchill, which was the last place where supplies could be obtained. A short distance north from Churchill the barren land commences, and no fuel can be got. The weather continued very cold, the thermometer frequently registering from $-10^{\circ}$ to $-15^{\circ}$ Fahr. The Eskimo, or Husky, who had so faithfully promised to return and meet me, had as yet shown no signs of putting in an appearance. Five weeks were passed at Churchill, the monotony of the life being broken by the occasional arrival of Huskies with loads of venison. A few Chipewyan Indians turned up, relating miserable stories of starvation during the winter months. The Huskies brought welcome news about the deer (caribou), which were reported to be very numerous all along the coast. I may 
here mention that the success of the whole journey, not my own particular one, but any expedition into the Barren North land, depends. entirely on the presence of deer in sufficient numbers along the route.

The season had now arrived for us to move on, if we wished to. have good ice to travel on as far as Chesterfield inlet. The Husky not having turned up, I engaged another Husky in his place"Milook," who agreed to accompany me as far as I wished, and who was capable of acting as guide as far as Marble island. We left Churchill on May 12 with two sleighs, twelve dogs, and four men, including the writer, all told. I took the precaution to haul a canoe along-for in the event of the polar bears having demolished the one left in cache near Marble island - not an unlikely contingency-we should have been placed in a decidedly awkward situation, being unable to return on the ice, and having no craft in which to proceed by water. Several nights' dried meat were taken for ourselves and the dogs, by which time we hoped to be amongst the caribou, or deer, as they are more commonly styled, A largo supply of tea and tobacco, and such articles for trading with the natives met with en route, as knives, files, beads, thimbles, needles, awls, etc., were included in our outfit. Supplie;, such as flour, bacon, sugær, etc., were dispensed with altogether. We were to depend henceforth on our rifles, guns, and nets to supply us with food.

Marble island was reached on June 5, and here we found the canoe. intact, just as it had been left the summer before, so the spare canoe was quickly broken up to supply some much-needed fuel. Travelling on the ice along the coast had on the whole been very good, and our progress, though slow, had been steady. Deer had been very scarce, and the dogs had starved several nights. The deer, which the Huskies had reported as being so plentiful a fow days north of Churchill, had all moved away inland, and only their tracks remained when we passed.

Many times did I deplore the folly of leaving Churchill with such a small quantity of dried meat. At one time it losked very much like having to beat a retreat back to Churchill, hauling our stuff on handsleighs. Fortunately, a few deer were met with and killed, just in time to save us from euch an ignominious course. I should hardly have dared to have shown my face bask at Churuhill, forced to turn back for a second time.

We had a great friend in the weather, which, with the exception of one blizzard, had been absolutely perfect-clear, bright, and cold. Those who know the climate of the Hudson bay may well be surprised. Such a long spell of glorious weather as we experienced the whole way up to Chesterfield inlet, and again up the inlet itself, has rarely been heard of before. As far as Marble island, the ice had not shown the slightest sign of breaking up, and the surface of it was as dry as in mid-winter. I thought several times of my two Cree lads from Oxford. House. If they had been along now, it would not have been possible No. I.-JuLY, 1900.] 
for them to have turned tail. There was no retreat now, for by this time the rivers to the south would be breaking up. We were burning the bridges behind us, so to speak.

The entrance to Chesterfield inlet was reached on June 8. The ice was still good to travel on, though the sun's power was commencing to show its effect, and numerous pools of water which lay on the ice had to be avoided if possible, otherwise splashed through. The weather continued perfect. It was hardly possible to believe that we were on the Hudson bay, a worse climate than which it would be difficult to find. Deer were shot as we wanted them, though at times they were. not so plentiful as might have been wished. Still, there was no starration either for ourselves or the dogs. Hunting delayed us a great deal, but large supplies of provisions would have delayed us very much more. In fact, it would not have been possible to have hauled up a sufficient supply of " outside stuff," i.e. flour, pork, sugar, etc., to have lasted the trip. As it was, my own and every available dog at Churchill had been requisitioned for the two sleighs. Obtaining a supply of meat would sometimes cause a delay of three days. Failing to sight deer on the first day would necessitate a second day being spent in hunting, and a third day was then required for hauling the meat. I used to shoot six or seven animals at the same spot, if possible. These would last us tbree days, when anotber halt would have to be called for hunting. Geese, ducks, ptarmigan, and other spring arrivals in the shape of small birds, hawks, loons, gulls, etc., began to appear at this time.

What at one time, in fact the whole way up, had caused me no little anxiety-viz. starvation on Chesterfield inlet while waiting for open water-now seemed very remote. The head of Chesterfield inlet was reached on June 21. During the latter part of the way up, travelling on the ice had become very bad. At one place the ice was so rough and hummocky, that the dogs' feet were cut to pieces, and I almost despaired of getting any further on the ice. By retracing our steps a long way, we managed to travel along the shore on the rafted ice, and so avoid the worst of the hummocky ice, which, when once we passed, gave us no further trouble; the ice became smooth again, and remained so until the head of the inlet was reached.

The last few days we had to travel in water the whole time, which was from 1 foot to 2 feet and over in depth, as it lay in large pools and small lakes on the ice. On several occasions some of the smaller dogs were actually swimming, and still trying to haul. The ice on the inlet was still 3 to 4 feet thick, but the snow, except in patches, had all disappeared from the Barren Ground. At the head of the inlet, some of the Baker Lake Huskies were met with. They appeared to be in a very starving condition, deer in the vicinity being very scarce, and they were without nets of any kind.

On June 23 a short portage was made over to Arkık, which is the 
Husky name for the deep bay of Baker lake which lies just to the south of Bowell island and the outlet from Baker lake into Chesterfield inlet. The canoe was hauled over by the dogs on bare ground, but all the stuff had to be packed over on our backs, the Huskies lending a willing hand. Arkok, on Baker lake, was reacbed on June 27, and here we were delayed for several days waiting for open water. We were then able to launch the canoe and kyaks, and proceed along the narrow strip of water which had already opened between the ice and the shore. At Arkok our nets kept us well supplied with fresh-run salmon, which average in weight from three to ten pounds. Following the south shore of Baker lake, the mouth of the Kazan river was reached on July 12, and here another delay of five days was necessary, the ice ahead on the lake being compact and solid. I now wished to obtain a supply of dried meat to take along in case of emergency. Deer, although fairly plentiful, were very difficult to get near, owing to the plague of mosquitoes, which was now at its height. The animals never remained quiet for a single instant. I managed always to kill enough for our immediate use by some very long range shooting. The flesh of the deer at this time was far from being palatable, and it was hardly fit to eat, being streaked with blood and foam all through. The marrow-a former luxury-was now of the consistency of blood and water, the inevitable result of " $\mathrm{fly}$ time," the wretched beasts being kept on the dead run day and night.

Baker lake is some 60 miles in length east and west. The head of it was reached on July 19. More of the Baker lake Huskies were met with at the head of the lake, at a place called King-ak, which is a deep bay to the south of the river flowing into Baker lake from Schultz lake. These natives were delighted to see "kablunak," or white people, again, and a present of tobacco completed their happiness. They willingly gave us assistance over the portage to the river, thus saving us going back a long distance and then round in order to reach the mouth of the river. Tracking the canoe and kyaks up the river for two days, Schultz lake was reached. Schultz lake and Aberdeen lake to the west of it are well known, and call for little notice. On Aberdeen lake, which is of considerable extent, we were delayed several days by head winds, and on one occasion were beset by ice, which even at this late date-July 31-had not all disappeared. However, by availing ourselves of every chance, and by travelling by night instead of by day, good progress was made. In the matter of light, the nights were now almost as clear as the days. Frequently I used to start to hunt deer at midnight.

At the head of Aberdeen lake deer were met with in large bands. They were now on their annual migration to the south. From now on, we never "hunted" deer-it was not necessary ; they could have been shot with a pistol from the tent door; one could almost catch them. Fish-large trout, whitefish, a few salmon, arctic trout, and one or two .other varieties--were taken by the nets in large quantities. In one niglit 
a single short net took over 100 lbs. weight. This was indeed a land of plenty, flowing with fish, deer, and small game.

On August 3 the mouth of the Doobaunt river was reached and passed, and we entered the Ark-e-leenik river (the Thelewdezeth of Back), which flows in from the west and joins the Doobaunt river. Large quantities of driftwood were found on its banks, for this river (Ark-e-leenik) is well wooded further west. Hitherto we had depended on woss and small heaths to provide a fire for cooking purposes.

We had now entered the unexplored country. How far west the Ark-e-leenik river would take us, whether it was navigable or not for canoes, were problems which we had come to solve. There was no information to be obtained from the Eskimo, for none of them had ever ascended the river for any distance. So without guides and without supplies of any kind, we started in to this unknown country, trusting to our rifles and nets to provide us with a living, and to the good fortune which up till now had come our way. The journey eventually turned out to be so absurdly easy, that I more than once regretted that it was so, for half the pleasure of exploration is derived from meeting and surmounting difficulties, i.e. providing, of course, they can be successfully surmounted without aluandoning most of one's stuff on the way. The main Ark-e-Leenik river was explored for a distance of 182 miles, and the western branch of it was ascended for 117 miles. The divide between the waters of the Hudson bay and Great Slave lake and the Mackenzie river was crossed at an altitude of 1394 feet, a short distancebeyond which we reached Clinton Colden lake, and our journey of exploration was safely accomplished. The Ark-e-Leenik is a fine large river about 300 yards wide, having an even steady current of from 4 to 5 miles an hour. For the entire distance of 182 miles which we followed the main river, there is not a sign of any rough water which could possibly be misinterpreted into the meaning of a rapid, and it is. navigable for a steamer with considerable draught nearly the whole way. About 50 miles from its mouth, wood (spruce) of fair-size growth is to be found, and the woods then increase in size and extent until the river divides, the larger branch coming in from the south, the smaller - which we followed up-joining from the west. The western branch, which was ascended for a distance of 117 miles, has numerous small and some large lakes on its upper waters. This branch of the Ark-e-leenik, although not free from rapids and rough water, presented no difficulties worth mentioning; a fow portages of a mile in length, one of 3 miles, and several smaller ones, and the large peculiar-shaped lake dotted in on most maps is reached.

We had long since left the limits of Huskyland, and were now (the upper waters of the western branch) well into the hunting-grounds of the Yellow Knives and Dog Ribs from Great Slave lake. Musk-ox were met with in large numbers on the main Ark-e-leenik river. There is a. 
stretch of country about 80 miles in extent into which no human being enters. The Eskimo do not hunt so far west; it is likewise too far distant for the Yellow Knives and Dog Ribs from Slave lake to enter. To penetrate this country in the dead of winter would be simply to court starvation. The deer have all departed, and to depend on finding musk-ox at the end of the journey would be risky indeed, for not enough meat could be hauled to see the party safely back through the barren and deserted country which would lay behind them. There still remains, I am happy to say, one spot in this Great Barren North landwhich is sacred to the musk-ox-into which human beings dare not enter. Here the animals remain in their primeval state, their solitude undisturbed by the hated sound and sight of man. Long may they remain so. The musk-ox were quite tame, and exhibited no fear, only curiosity. I approached several herds within 30 yards, photographed them at my leisure, moving them round as I wished, and then retired, leaving them still stupidly staring at me in wonder and amazement. When deer were not procurable-and several times we seem to have run out of them altogether-a musk-ox was killed. Fish were plentiful all along the Ark-e-leenik ; in fact, I never saw such a grand river for fish. The nets were rarely set, however, when meat was procurable, as it caused considerable delay in the morning, and the nets had to be dried. Moose are to be found on the main Ark-e-leenik, also black bears. On the western branch the woots decrease in size and extent as one ascends, until finally at the height of land there are none, and once more we had to fall back on moss and heaths for fuel. Deer were then very scarce, and the musk-ox we had long since left behind, but something always turned up to keep the pot boiling. One day it would be a wolverine, another time a fat wolf; all animals appear to be good on the Barren Lands, or is it that one's appetite is good? An occasional goose was shot, ducks, ptarmigan, an arctic hare; we always had enough, anyway, and one soon ceases to be particular as to exactly what kind of an animal it is which satisfies one's hunger.

We had the good luck to meet the Eskimo from the arctic coast on the Ark-e-leenik river, who resort to this river to obtain wood for their sleighs. These natives had never set eyes on a white man before, and had no articles of civilization whatever. They were all dressed in deerskins, and armed with long bows, arrows, and spears, beaten out of native copper. The use of tobacco was quite unknown to them, and firearms they had only heard about. They gave me a good deal of information about their country and the copper deposits along the arctic coast, and I obtained from them several copper implements, such as dags, spear and arrow heads, needles, etc., which were all beaten out of native copper, giving them in exchange knives, files, and needles, which last appeared to have by far the most value in their eyes. They exbibited no signs of fear at our approach. They were a jovial lot, and 
camped with us that night. In the evening they sang together, rather nicely, I thought. The next morning we parted, with many signs of friendship on their part.

On Clinton Colden lake, a very incorrect Dominion Government map in my possession was the cause of our going close on 100 miles out of our way. From Clinton Colden lake to Fond-du-lac on Great Slave lake, the geography of the country is well known, if not very accurately surveyed. On Artillery lake we struck the green spruce woods again about halfway down, and there we bade a final farewell to. the Barren Northland, over which we had journeyed for well-nigh four months, and which had treated us so hospitably. The river flowing. from the foot of Artillery lake into Great Slave lake is only passable for canoes the first 5 miles or so, beyond which distance the river descends torrent fashion through a deep precipitous chasm to Great Slave lake.

We had made several short portages on the unlucky day of the disastrous canoe accident, and already it was getting on for campingtime. In letting the canoe down a small side rapid by a bow-and-stern line, the stern line parted, and the tail of the canoe was quickly swung, out into the current. In an instant it was caught by the rapids, and the bow line wrenched from the grasp of the man who held it. It all happened in a second. A cry of despair from one of my men, and we ran wildly down the river in the vain hope of the small craft being. caught by some side eddy, and so brought close enough to the shore to get hold of. It shot the first rapid broadside on, even survived through. the second without capsizing. A faint gleam of hope sprang up in my breast, but only for a second. A glance ahead down the river quickly dispelled any such hopes. The waters ahead, toward which the small canoe was being hurried, were all white, one broad expanse of seething. foam, from which the tops of black rocks protruded in ominous fashion. The next time I lifted my eyes to look, the canoe was being tossed about, bottom up, amid one sea of foam, and the stuff, such of it as floated, was being swept away down to the rapids below in scattered directions. My heart sank; everything we possessed had disappeared-all gone! Rifles, guns, nets, axes, instruments, cameras, collections of geological and botanical specimens, note-books, and my precious photos, the result of a whole summer's work irretrievably lost! Even the canoe itself was soon lost sight of, and we were left with absolutely nothing. but the clothes we stood in, still staring vacantly at the raging river which seemel to hold us with a certain fascination. My first impulse was to feel in my pockets for matches, and to my joy I discovered nine dry reliable wax matches, each one of which was good for a fire. This meant nine nights' fire, anyway. To cut a long story short, the canoe was eventually recovered, also a box, in which were my note-books and diaries containing the record of the journey, and a fow other things. The loss of the geological and botanical collections, 
on which I had spent much time and trouble, I particularly regret; the loss of an exceptionally interesting collection of photos I deplore.

By the loss of the rifles, guns, and nets, we were now without the means of procuring food, and were in the middle of a very rough country. Deer were plentiful, and stoo $l$ stupidly staring at us within easy range; fish were leaping in the pools on the river, but the means of killing deer or taking fish were gone. Not an enviable situation in which to find one's self, and a very disastrous finish-up to an otberwise successful and most onjoyable journey. For six days we livel on what cranberries and blueberries we could find. We then fell in with the Yellow Knives, many of whom I knew. From them I obtained some dried meat, sufficient to take us to Fort Resolution on Great Slave lake, where we safely landed on September 25. At Resolution we heard all about the Great Slave Lake Mining bubble, which had finally burst, leaving many, I am afraid, richer in experience, if not in pocket. There still being a chance of reaching Athabasca Landing by open water, I availed myself of it, only remaining at Resolution a couple of days to get some very necessary clothes and footgear. A fresh start for the south was made on September 28, but we only reached as far as Red River post, 35 miles north from Fort McMurray, when the ice stopped us on October 17. The rest of the journey was accomplished with $\operatorname{dog} s$.

\section{APPENDIX.}

\section{Geological Data.}

June 5.-Rocks at Eskimo camp, near Marble island, large outcrop of dark green schists; fragments of white quartzite along the shore. North of this, for some distance, no rocks in situ; fragmentary rocks scattered around were gueiss of varied colour, mostly light grey, containing black and white mic These specimens were smoothed and rounded, and have evidently been transported.

June 8.-Snall island off the coast, about 5 miles south of the entrance to Cape Inlet: rocks in situ grey gneiss, cut in different directions by veins of red or flesh-coloured granite, dipping east at a low angle. Wag island, composed of light grey gneiss and some darker coloured, containing hornblende horizontally lying, well s noothed and grooved by glicial action; no striæ observed, but the ice ruoved over this part in a south-south-east direction; vegetation on island very scanty.

June 10.-Neck of land connecting Variety point with south shore of Cape Inlet : similar greiss, horizontally bedded, cut by veins of granite; smoothed and grooved, but no striation. Hill to the south on mainland, similar formation; dip almost vertical. On the top of hill, an extensive heap of loose, smooth, and rounded boulders, and stones of gneiss (terminal moraine?).

June 12.-Large island in Capł Inlet, be sring west-south-west from Dangerous point: goeiss associated with red granite; in places huge blocks upheıved and thrown out of place by frost action; beds dipping west at an angle of $45^{\circ}$. Puint 80 miles west of Dangeruus point ; coarse-grained gneiss with granite ; dipping at angle of $40^{\circ}$. Other places in Cape Inlet have been noticed in Mr. Tyrrell's report.

June 26.-Arkok ( $a$ bay to the south of B Jwell island): first signs of sandstone (red) formation, fragmentary only; no rock in situ.

June 27.-West point of Bcwell island, betwesn soath outle ${ }_{\lrcorner}$of Baker lake and. 
Arkok : large outcrop of sandstone; conglomerate; very little sandstone pure. The conglomerate contains quartzite pebbles, some very large, very hard to break with an axe; dipping south-west at various angles. Fragments and large slabs, some with ripple-marks of pure red sandstone lying around, and shares composed of sandstone débris. No othər formation in situ, but scattered fragments and small boulders of gneiss chiefly.

June 30.-South shore of Baker lake, opposite Maur-en-ik-nak. Exposures appear a short distance inland, in the form of large oval-shaped mounds, which cap the small hil's rising from the undulating grass-covered flats. Specimen 4, obtained close to camp from rock in situ, a schist, apparently, though the rock has rather the character of a fine or medium grained thin-bedded gneiss, of a dark grey or greenish colour, breaking easily when struck with an axe, with a slatey cleavage; the rock is cut by veins of white quartz, and blotched with same; surface of rock smoothed and rounded ; dipping west-north-west at an angle of $50^{\circ}$. Another specimen, also numbered 4, from further inland: a small exposure, surface of rock much disintegrated by frost; no sandstone in situ, but abundant evidence of this formation existing in the vicinity, from the number of rounded stones lying around everywhere; the small circular gravel terraces, as seen everywhere on the Barren Land, much in evidence; broad and extensive low ridges, generally flat-topped, on which are piles or groups of stones; small beds and bunks, and lying around on gravel surfaces between the numerous large and small lakes are shells innumerable.

July 3.-Tuok specimens of shells, which here, head of Arkok, form the subsoil, or, rather, a bed of these shells, from $1 \frac{1}{2}$ to 2 feet thick, underlies the thin layer of soil, which supports a growth of moss and grass. This bed of shells extends continuously fur over a mile from the shore, perbaps further. For 6 miles distant they were still to be seen at the elge of and between small lakes-in fact, everywhere where the ground was not covered by a growth of moss and grass. They were observed at a height of about 100 feet from the lake. (Specimens of these shells and a few rock specimens will be sent out from Churchill.)

July 5.-From head of Arkok, west-north-west along Baker lake : more extensive oval or mound-shaped exp sures of similar rock, which now assume the character of ridges descending abruptly to the shore; lind beyond flat, with low shores, covered with sandstone débris. Sixteen miles west-north-west from head of Arkok, at the mouth of a small river: exposure of red or reddish-brown sandstone in bel of river, extending for 80 yards north and south, and about 25 yards east and west; beds $1 \frac{1}{2}$ to $2 \frac{1}{2}$ feet thick, dipping west at an angle of $8^{\circ}$. This exposure is 6 feet below the east bank of the river, is smooth and striated, striæ trending soutb. One mile further on, small mound or oval-shaped outcrop of red sandstone close to the shore, surface much affecte $I$ by weather.

July 9.-Proceeding along south shore of Baker lake, numerous exposures of red sandstone along the shore. At 9 miles there is an extensive area about half a mile long by 250 yards wide, covere 1 by a thro $x$ of smallish flat angular-shaped pieces of sandstone, which lie in the form of regular layers, or steps, as they slope towards the shore. Surely these parts could never hive been swept over by fields of ice? A curious rucky exposure of red sandstone close by, the jagged surfaces of the beds projucting perpend cularly. Difficult to ascertain the dip, but the beds facing north are perpendicularly broken off. A short distance further on, sandstone beds dip south-west at an angle of $42^{\circ}$. Two miles inland mound-shaped sandstone hills; with the exception of these, land is dead flat, with numerous lakes scattered around.

July 11.-Along south shore of Baker lake to mouth of Kazan river : no rocks in situ; sandstone boulders and débris abundant.

July 12 and 14.-East side of mouth of Kaz nn river: no exposures; loose 
boulders, gravel, dirt; shores sandy. Ssveral miles to the south Kazan river cuts through a range of hills. Did not have opportunity of visiting them.

July 15.-West side of mouth of Kazan river: land extending from shore for 2 miles inland, dead, flat, and dotted with small lakes innumerable; then rising to a height which gives it the appearance of a long low ridge, as viewed from away east; sandstone beds here showing. Wherever sandstone formation exists, the land flat or slightly undulating, and grass-covered.

July 16.-Ascended rising land in form of a ridge, which lies to south-west of the mouth of Kazan river, which has an altitude of from 300 to 400 feet above the level of the lake. Exposure of sandstone on summit of ridge, which has the appearance of a rather altered rock. Dip difficult to determine; all that could be seen were small pieces of rock projecting perpзndicularly. Surface of the main bed which showed was smoothed and rounded; terraces, semicircular or rim-shaped, at summit of ridge, composed of angular and irregular shaped fragments of sandstone, some of it differing from that in situ.

July 21.-On the portage between King-ak (which is a deep bay to the south . of the mouth of river flowing from Schultz into Baker lake) and Koo-ook (which is the name of the river itself), which we struck 2 miles up from its mouth, we passed over several low ridges, all fulspathic granite, cut by veins and associated with quartz; beds horizontally lying. Distance across portage, 5 miles.

July 22. - Travelled 14 miles up Koo-ook. Granitic formation; this granite in some places contain hornblende, in others it is of a felspathic character, the felspar - occasionally being very much in the ascendant. Ridges, which run parallel to Iiver on the south side and about one mile distant, all similar, cut by narrow veins, and assoziated with white quartz, occasionally in large quantities. Exposures numerous; beds mostly horizontally placed; smoothed and grooved. North-east side of river not examined, but more rocky than south-west side.

July 23.-Proceeding up Koo-ook. Scattered fragments along the shore, giving evidence of a new formation in the vicinity, which we struck after travelling 4 miles-a greenish or grey-coloured schist, having a very slatey cleavage. Large exposures along ridges south-west of the river; general dip of beds nearly vertical. A short distance further on, this rock is cut by a vein of white quartz 10 feet thick, and in many places by smaller veins. At 13 miles the river cuts through this rock to a depth of 80 feet; the rock on south side is deeply grooved by glacial action. A short distance inland, large slabs have been uplifted from the matrix by the action of frost, and are left sticking up, resembling large slabs of slate upended.

July 24.-Went on 7 miles up Koo-ook. Rocks similar schists, at one place dipping south-east at an angle of $60^{\circ}$.

July 25.-Reached the rapids near east end of Schultz lake after travelling 2 miles. Just above the rapid, granitic furmation again. Similar, although varying sli.hhtly in character, to the rocks on King-a's portage. One outcrop appeared to be a granitoid gneiss. Extensive exposures on both sides of river. Dip of beds at one place north $25^{\circ} \mathrm{W}$. at an angle of $40^{\circ}$. East end of Schultz lake, granitoid gneiss; 10 miles up the like on north side, and a short distance inland, exposure of very coarse-grained red or brown sandstone. On the top of these beds, and also near by, rested some huge circular chunks of conglomerate, in which were embedded large quartzite pebbles, some of them the size of a man's head.'

July 26.-Delıyed by heavy head winds; took a walk back from camp, i.e. north-east. Rocks, conglomerate predominating, containing usual quartzite pebbles. .$A$ few exposures of red-brown, very coarse-grained, quartzitic sandstone.

July 31.-East e dd of Aberdeen lake. Rocks in situ ; conglomerate and sandstone, thick and horizontally bedded. Proceeding along north shore as far as 
Kek-ek-tellig, white sandstone débris. (Kek-ek-tellig, by the way, is where the Doobaunt river enters Aberdeen lake.)

August 3.-Between Kek-ek-tellig and mouth of Doobaunt river. Boulders on the shore very varied, granitic predominating; also sowe of gneiss, greenstone, angular quartzite, conglomerate, sandstone, etc.

August 5.-No rocks in situ until to-day at noon, when we were 33 miles u?! the Ark-e-leenik (Thelew) river: outcrop of fine-grained, purply coloured sandstone, dipping north $15^{\circ} \mathrm{E}$. at an angle of $30^{\circ}$ in bed of river; surface of rock much jagged and broken. It occurs on north-east side of river, and is of considerable extent; the high-cut banks, between which the river flows, are of sand and loam; outcrops of rock on hills some distance away to the south-east, probably sandstone.

August 11. - No rock in situ until to-day. We have been passing through a very flat and occasionally undulating country, without not even a small hill in sight. It is evidently sandstone all through. Rঃd and white sandstone débris scattered along both shores. Exposure of white sandstone, very thin and horizontally bedded, in the bed and on both sides of river, extending for about 200 . yards (this would be about 94 miles up the Ark-e-leenik river).

August 12.-Camp about 120 miles up the Ark-e-leenik, 2 miles above our camp of last night. Horizontally and thick-bedded red sandstone, well shown in precipitously cut bank on west side of river, and similar exposures were seen at a dozen or more different places passed to-day. Some of these cut banks exposed the sandstone beds to the depth of 50 feet; they occur on both sides of the river. Stratification well shown in many of them. Near camp of last night, outcropon the top of a small longish, low hill, east of river, appeared white-probably white sandstone, but possibly limestone; small fragments of the latter noticed on the small circular terraces uot far distant. Did not have an opportunity to visit the hill. Twelve miles up the river from camp, many large loose boulders piled up by the ice on east side of river; some of them beautiful specimens of granite, others of gneiss; greenstone noticed. But the large majority of the boulders were of a kind of hardened shale, surfaces of which ware a dullish white and resembled limestone on the outside; in form they were mosily angular, but the edges were smoothed and rounded.

August 13.-Continuing up the river, we passed on the east side of the river an exposure of thin-bedded, horizontally placed red sandstone, deeply and distinctly score 1, stria south-east; parts of the surfaces bore ripple-markings.

August 16.-About 170 miles up the Ark-e-leenik river, approaching a range of hills of moderate height, which it entered through a short gorge after we had travelled 4 miles. An almost precipitous hill, aboat 600 feet in height, confines the river on the left-hand side at this spot, the lower part of which is one confused mass of large, loose white sandstone fragments, which have fallen and slipped from above, where the rock is in situ, horizontally bedded. A spur or ridge from this hill or peak extends up the river for some distance, and is of the same formation. Character of country beyond gorge extremely sandy, the sand being beautifully white. About 7 miles beyond the gorge the Ark-e-leenik river divides, the larger branch cutting its way through thick beds of horizontally lying, red and white, chiefly white, sandstone, and flows off in a south-east direction, the smaller branch, which I followed, taking a south and changing course. I shall refer to this now as the west branch of the Ark-e-leenik. A bill lying to the west between the gorge and the forks, a typically glaciated sandstone hill.

August 17.-We now ascended the main Ark-e-lecnik river for a distance of 182 miles. Proceeding up the western branch, white sandstone formation very evident, river cutting its way through thick beds at several places. At 3 miles from the forks a fall of 5 fett, white sandstone bzds horizontally placed exposed; 
balf a mile beyond, a fine fall of 30 feet; horizontal beds of white sandstone cut precipitously for a distance of 150 yards. Rock appears to be very soft, and easily crumbles; surface on east or north side of fall, near the edge, well smoothed and very distinctly striated, striæ $\mathrm{S} .20^{\circ} \mathrm{E}$.

August 18.-At last we come on a change from the everlasting sandstone, which formation continues the whole way up the Ark-e-leenik river. At about 12 miles the western branch cuts through a thick bed of gabbro (?), which extends in the form of a deepish gorge for 200 yards; this rock is very massive, beds dipping south at an angle of $60^{\circ}$. Rock varies in character, some of it having the appearance of a foliated rock on the outside. Quartz very much in the ascendant in some cases; biolite in others. In places the rock is largely composed of a flesh-coloured stuff, with only a thin layer of the matrix rock appearing. A dark green rock is much in evidence in many cases. Twenty feet or more of this formation is cut through by the river at this spot. Half a mile beyond, the confounded white sandstone appears again; I thought that we had seen the last of it. Huge chunks are piled around. in a confused mass in a small gorge, the rock itself also being seen in situ.

August 19.-A very short distance beyond this small gorge, the river flows through a deep gorge 40 to 100 feet deep. At the commencement of this gorge, and extending for a distance of 500 yards, the beds cut through are now the familiar white and reddish sandstones containing quartzite pebbles, mostly small; same. rock on both sides of the river. On the north-east side beds are thin and horizontal; on the south-west side beds are thick and falsely bedded. Beyond this sandstone, which extends up 500 yards, the formation changes; Laurentian gneiss appears. The junction of the two formations is not very distinct, for a small landslide has taken place at this spot, but the difference in the colour of the soil is very apparent; the white sandy soil of the sandstone and the reddish purple of the new formation lie side by side; the gneiss extends up the gorge for a mile, and above it again crops out, extending also up small side gulchez which adjoin the river. This rock has a very distinct foliation on the outside, more so than when broken. Breaks with a slatey cleavage. It is much broken up, up-ended, and generally jumbled about in the gorge, but dips east at a very high angle, almost vertical. Width of river at this point, $860 \mathrm{feet}$. Loose rocks of gneiss scattered around for 2 miles beyond the gorge.

August 20.-Travelled 12 miles up the river. Gneiss crops out all along in bed of river and at several othe: places, varying in character in different places.

August 21.-Proceeded up river to small lake. Rocks here, red granite (felspathic); very rocky country. Took a long walk in afternoon; rocks all the samered granite in situ, and scattered boulders and fragments. Gneiss does not appear in situ, but boulders and fragments of it, irregular, angular, and sbarp-edged; plentiful.

August 22.-Fourteen and a half miles up river. Land very flat and sandy, some high sand hills and knolls in view. At 5 miles, beds of red granite are cut by a thick vein of white quartz, in which nothing is visible. Vein running north and south (true) in furm of a small ridge 70 yards by 15 yards. This was on south. side of river. One and a half mile further up, outcrop of dark grey rock; very brittle, and splits up into small sections when tapped with the axe. Outcrop in bed of a small stream, coming in from the south; exposure about 40 yards in. extent, dipping S. $30^{\circ} \mathrm{E}$. at an angle of $60^{\circ}$. At 12 miles river cuts through a bed of Laurentian or granitoid gneiss, mostly grey in colour, but some reldish; horizontally be dded, smoothed, but not striated. Noticed several small outcrops of this rock yesterday and this morning, but the chief formation is the red granite. The curious balanced stones observed to-day for the first time.

August 25.-Travelled 6 miles. Barren land here terribly rocky-miles of looserocks and boulders; red granite and granitoid gneiss. But I had little time to. geologize, for I had to hunt up the blessed river, which we had lost in a lake. 
August 28.-Camp at small lake leading into Kasba lake. Small outcrop of mica schist; a smooth low rock, full of small water-holes, sloping gently to water's edge; other rocks same as before, chiefly granite.

August 29.-Suuth side of the divide (a short distance east of Clinto Colden lake). Quartzitic grey granite, dipping south-east at an angle of $75^{\circ}$; red granite, also in evidence a shurt distance east. Last sight of Laurentian gneiss, but it may be present. Had but little time to look around, as I was busy portaging.

August 31.-Fine-grained basalt(?) diorite (?) obtained from a highish rocky island, north-east end of Clinton Colden lake, rock sluping south-east to water's edge, smoothed and striated, striæ south-south-east; island 7 miles west from east end of lake.

September 1.-North-west end of Clinton Colden lake. Rocks, grey granite; a great deal of it; country very rocky.

September 2.-Went up strait between Aylmer and Clinton Colden lakes; coarsegrained biotite, quartzitic grey granite. Biotite occurs in small chunks, and the rock is very full of it in smaller pieces. Rocks much displaced, and a rough country. Some of the granite is red, in which felspar is very much in evidence.

September 3.-Along the south shore of Clinton C:slden lake. Huge fragmentary rocks; where the rock is in situ it is smooth (waterworn) and slopes to the water's edge; no striation or grooves. The rock appears to have a certain fo'iation, and is associated with quartz in places; this rock, which I failed to classify, and the grey biotite granite are the distinctive rocks along the shore passed to-day. At two places the rock dips north at a high and low angle.

September 5.-Six miles south of narrows leading from Clinton Colden lake, similar rock to that on the King-ak portage (July 21)-pink felspathic granite. Rock sloping to water's $\epsilon$ dge; no definite dip and no stria, but smoothed.

September 6.-River between Clinton Colden lake and Artillery lake, grey and fel-pathic granite cccurs along the banks. In places the country is of a very sandy nature.

Sextember 7.-Twenty-two miles south from head of Artillery lake, and on the west side. This rock (specimens have been lost, of course) occurs all along the west shore to our present camp, which is 36 miles from the head of the lake, the grey and felspathic granite only occasionally appearing. I called it an altered limestone (?) There are large outcrops of it all along; quartz being much in evidence in veins, pebbles, and small chunks. Oa the outside of the rock the quartz appears in queershaped excrescences, which run along in the form of ridges, giving the rock a banded appearance. The matrix is brown on the outside, grey inside; very hard. Ambercoloured q'artz crystals in the furm of sexagonal pyramids, also milk-white ditto, were very common, and some beautiful specimens were taken. The rock itself reminded me of the boulders found on the Ark-e-leenik river (August 12). These boulders appeared to be compused of a hardened shale, and were a dullish white on the outside, and this rock has a brown appearance on the outside, but to the eye they appeared to ba of the sams composition. At the foot of the Artillery lake, at the outlet, there is a vein of discoloured quartz containing large quantities of iron. I have a specimen of this; the rocks were granitic again, and this was the last place where any notice was taken of the rocks, for o:ur trouble then commenced.

Slave lake has by this time been fully reported on. Sandstone occurs on some of the islands near Fond-du-lac.

In the foregoing notes, on the days which are missed, it must be supposed that the formation of the previous day or days continued, or else that no rocks were met with. There were no fossils to be fuund in the sandstone, although I searched diligently for them at several placts. 


\begin{tabular}{|c|c|c|c|c|c|}
\hline \multirow[b]{2}{*}{ ate } & \multicolumn{2}{|c|}{ Bar. } & \multicolumn{2}{|c|}{ Ther. } & \multirow[b]{2}{*}{ Remarks. } \\
\hline & $\begin{array}{l}\text { gं } \\
\alpha \\
0 \\
0\end{array}$ & $\begin{array}{l}g \\
\dot{D} \\
0\end{array}$ & & 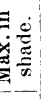 & \\
\hline ay & & & & o & \\
\hline 12 & & $30 \cdot 08$ & 11 & - & Left Churchill. \\
\hline $\begin{array}{l}13 \\
14\end{array}$ & $\begin{array}{l}30 \cdot 10 \\
30 \cdot 28\end{array}$ & $30 \cdot 21$ & & - & Cold and cloudy, wind N.W. \\
\hline 15 & $30 \cdot 22$ & & 6 & - & Wind $\mathrm{N}$. \\
\hline & $30 \cdot 04$ & $30 \cdot 10$ & & - & Warm day, wind $W$. \\
\hline 17 & $30 \cdot 12$ & $30 \cdot 13$ & 0 & - & Wind S.E. \\
\hline $\begin{array}{l}18 \\
19\end{array}$ & $\begin{array}{l}30 \cdot 13 \\
30 \cdot 03\end{array}$ & & & - & 20 miles south of Eskimo point. \\
\hline 20 & $30 \cdot 13$ & & & - & Cool and cloudy, wind $S$. \\
\hline 21 & $30 \cdot 11$ & $29 \cdot 88$ & & - & Inland from Eskimo point. \\
\hline $\begin{array}{l}22 \\
23\end{array}$ & $\mid \begin{array}{l}29 \cdot 48 \\
30 \cdot 00\end{array}$ & $\mid 29 \cdot 89$ & 27 & - & $\begin{array}{l}\text { Eskimo point 9. A blizzard. } \\
\text { gentle breeze N.W. }\end{array}$ \\
\hline 24 & $\begin{array}{l}30 \cdot 00 \\
29 \cdot 81\end{array}$ & $29 \cdot 96$ & $\begin{array}{c}4 \\
18\end{array}$ & 二 & $\begin{array}{l}\text { ", wentle breeze N.W. } \\
\text { wind N.E., thick } \\
\text { and snowing. }\end{array}$ \\
\hline 25 & $29 \cdot 78$ & $29 \cdot 86$ & 18 & - & $\begin{array}{l}\text { wind N.W., blow- } \\
\text { ing and dr.fting. }\end{array}$ \\
\hline $\begin{array}{l}26 \\
27\end{array}$ & $\begin{array}{l}29 \cdot 98 \\
29 \cdot 94\end{array}$ & $\begin{array}{l}29 \cdot 95 \\
29 \cdot 95\end{array}$ & $\begin{array}{l}12 \\
12\end{array}$ & 二 & Left Eskimo point. Wind S.E., \\
\hline 28 & & & & 一 & $\begin{array}{l}\text { mild and cloudy. } \\
\text { Wind S.E., dull and cloudy. }\end{array}$ \\
\hline 29 & $29 \cdot 86$ & $29 \cdot 87$ & & - & Wind N. and N.E., cool and \\
\hline 30 & $29 \cdot 88$ & $29 \cdot 95$ & 25 & - & Wiud N.W., dull and cloudy. \\
\hline 31 & $30 \cdot 00$ & $29 \cdot 96$ & & 56 & $\begin{array}{l}\text { Wind N.W., thawing in after- } \\
\text { noon. }\end{array}$ \\
\hline$\underset{1}{\operatorname{June}}$ & 30.04 & & & 65 & Wind \\
\hline 2 & 30.02 & $30 \cdot 00$ & & - & $\begin{array}{l}\text { Wind N.W. W., bitterly cold. Term } \\
\text { point. }\end{array}$ \\
\hline 3 & $29 \cdot 92$ & $29 \cdot 90$ & 20 & - & $\begin{array}{l}\text { Wind S.E., fine, Left Term } \\
\text { point. }\end{array}$ \\
\hline 4 & $29 \cdot 89$ & $29 \cdot 92$ & 224 & - & $\begin{array}{l}\text { Misty in morning, clear in } \\
\text { afternoon. }\end{array}$ \\
\hline 5 & $29 \cdot 98$ & $30 \cdot 17$ & 715 & - & $\begin{array}{l}\text { Wind S.E.E., warm and hazy } \\
\text { on Marble island. }\end{array}$ \\
\hline 6 & $30 \cdot 20$ & $30 \cdot 04$ & & 63 & $\begin{array}{l}\text { Wind S., fine and calm, snow } \\
\text { fast melting. }\end{array}$ \\
\hline 7 & $29 \cdot 96$ & $629 \cdot 80$ & 028 & - & $\begin{array}{l}\text { Wind S.W. Left Marble lake, } \\
\text { arrived Baker's foreland. }\end{array}$ \\
\hline 8 & $29 \cdot 72$ & $29 \cdot 70$ & 033 & - & $\begin{array}{l}\text { Wind } N \text {. W. gentle breeze; } 16 \\
\text { miles south of inlet. }\end{array}$ \\
\hline 9 & $29 \cdot 67$ & 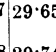 & 533 & - & Wind $W$. , hot and bright. Wag \\
\hline 10 & $-9 \cdot 68$ & $\cdot 74$ & 434 & - & $\begin{array}{l}\text { No wind, perfect day. Variety } \\
\text { point. }\end{array}$ \\
\hline 11 & $29 \cdot 68$ & $829 \cdot 6$ & 324 & $\begin{array}{c}73 \\
\text { (in }\end{array}$ & Gentle S. breeze. \\
\hline & & & & sun) & \\
\hline 12 & 2900 & $29 \cdot 6$ & 733 & & $\begin{array}{l}\text { Wind S.W., dull and cloudy. } \\
\text { Left Variety point. }\end{array}$ \\
\hline $\begin{array}{l}13 \\
14\end{array}$ & $29 \cdot 8$ & $029 \cdot 8$ & 522 & 二 & Near Dangerous point. \\
\hline 14 & $29^{\circ}$ & $829 \cdot 6$ & & - & $\begin{array}{l}\text { Wind S.W., strong, fine day, } \\
\text { south-west of Dangerous point. }\end{array}$ \\
\hline 15 & $29 \cdot 50$ & $029 \cdot 5$ & 324 & 58 & $\begin{array}{l}\text { Rain, heavy shower in after- } \\
\text { noon. }\end{array}$ \\
\hline 16 & $\begin{array}{l}29 \cdot 64 \\
29 \cdot 64\end{array}$ & & 432 & $\begin{array}{l}50 \\
56\end{array}$ & Wind W., dull ; clear in evening. \\
\hline $\begin{array}{l}17 \\
18\end{array}$ & $29 \cdot 73$ & $329 \cdot 6$ & & $\frac{56}{-}$ & snow in morning, near \\
\hline 19 & $29 \cdot 6$ & $029 \cdot 6$ & 3031 & - & $\begin{array}{l}\text { North river, Cape inlet. } \\
\text { Wind W.; fine near Stony point. }\end{array}$ \\
\hline 20 & $29 \cdot 64$ & $429 \cdot 7$ & & - & Wind S.W., fine, gentle breeze. \\
\hline 21 & $29 \cdot 76$ & $629 \cdot 7$ & & 63 & $\begin{array}{l}\text { Wind N.W., fine. Near mouth } \\
\text { of Quoich river. }\end{array}$ \\
\hline 22 & $29 \cdot 7_{2}$ & $2 \mid 29 \cdot 7$ & 7532 & - & $\begin{array}{l}\text { Variable light airs, fine. Bowell } \\
\text { island }\end{array}$ \\
\hline 23 & $29 \cdot 8$ & $230 \cdot 0$ & 438 & - & Wind N.W. ; rain last night. \\
\hline 24 & 30.07 & $7 \mid 30 \cdot 0$ & & 64 & No wind, $f$ \\
\hline 25 & 30.0 & $2 \cdot 30 \cdot 0$ & & 63 & Wind S.E., strong. Baker lake. \\
\hline 26 & $30 \cdot 13$ & $30^{3 \cdot 1}$ & $12 \begin{array}{ll}3 & 35 \\
13 & 29\end{array}$ & $\overline{-}$ & Wind S.E., gentle. \\
\hline $\begin{array}{l}27 \\
28\end{array}$ & $30 \cdot 18$ & $\begin{array}{l}8 \\
\begin{array}{l}8 \\
4\end{array} 29 \cdot 9\end{array}$ & $\begin{array}{l}13 \\
97 \\
31\end{array}$ & $\overline{66}$ & Wind S., strong; weather fine. \\
\hline 29 & $29 \cdot 98$ & $829 \cdot 6$ & & - & Wind S., moderate. \\
\hline $\begin{array}{l}30 \\
\text { July }\end{array}$ & $29 \cdot 51$ & $129 \cdot 4$ & & 63 & \\
\hline 1 & $29 \cdot 57$ & $7^{7} 29 \cdot 5$ & $58 \mid 28$ & - & Wind $\mathbf{N} . W$. \\
\hline & $29 \cdot 60$ & $029 \cdot 6$ & 6236 & & \\
\hline 3 & $29 \cdot 6$ & $229 \cdot 5$ & 5436 & 58 & Wind $\mathbf{N} . \mathrm{I}$ \\
\hline $\begin{array}{l}4 \\
5\end{array}$ & $29 \cdot 65$ & $3329 \cdot 7$ & 7336 & 53 & 1 and cloudy. \\
\hline 5 & $29 \cdot 9$ & $629 \cdot 7$ & 7838 & $\begin{array}{l}65 \\
72\end{array}$ & $\begin{array}{l}\text { Wind S.E., hot ; sunny in morn- } \\
\text { ing, overcast in evening. }\end{array}$ \\
\hline $\begin{array}{l}7 \\
8\end{array}$ & {$\left[\begin{array}{l}29 \cdot 6 \\
29 \cdot 6\end{array}\right.$} & $729 \cdot 7$ & $\begin{array}{l}7042 \\
5133\end{array}$ & $\frac{62}{-}$ & $\begin{array}{l}\text { Wind N.W.; rain last night. } \\
\text { Wind S.E., strong. Lefi east }\end{array}$ \\
\hline 9 & $29 \cdot 6$ & 3829 & 7032 & 53 & $\begin{array}{l}\text { Wind N.W.; heavy rain last } \\
\text { night. }\end{array}$ \\
\hline 10 & $29 \cdot 6$ & $31 / 28$ & & - & $\begin{array}{l}\text { Travelling west towards Kazan } \\
\text { river. }\end{array}$ \\
\hline 11 & $29 \cdot 7$ & $8929 \cdot 7$ & & 80 & Wind S.S.W. \\
\hline
\end{tabular}

Bar. Ther.

Date

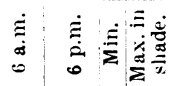

Remarks.

July

12 29.70 29.68 - - Wind S., fiue

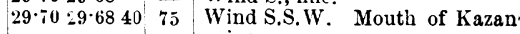

$29 \cdot 7529 \cdot 8742-$ Wind N.N.W., rain in morning.

30.03 29.92 $39 \quad 58$ Mouth of Kazan river.

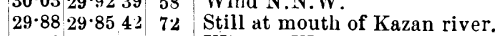

$30 \cdot 0030.043463$ Wind N.W., fine.

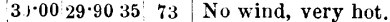

29.7829 .6342 - Wind E. Started west from Kazan river.

29.5829 .6242 - Wind N.E., thick mist. West end Baker lake.

$29 \cdot 72 \cdot 29 \cdot 76-64$ Fine. West end of Baker lake. $29 \cdot 8029 \cdot 6037$ - Wind W.

$29 \cdot 6129 \cdot 6045$ $29 \cdot 70 \cdot 29 \cdot 4138=$

East 'end of Schultz lake.

$29 \cdot 1329 \cdot 2543 \quad 52$ Heavy rain-storm in morning from S.E.

$29 \cdot 30,29 \cdot 1333 \quad 58$ Wind W., light.

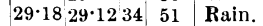

$29 \cdot 1529 \cdot 163559$ Wind N.W. West end of

$29 \cdot 1829 \cdot 1832-$ Wind W.N.W. East end of Aberdetn lake.

\begin{tabular}{lll|l}
$29 \cdot 20$ & $29 \cdot 30.29$ & 54 & Strong N.W and W.N.W. winds
\end{tabular} the last few days.

$29 \cdot 4529 \cdot 36$ 38 56 Strong W.N.W. On Aberdeen lake.

$3 \quad 29 \cdot 30 \cdot 29 \cdot 3343$ - Strong N.W.E. West end Aberdeen lake.

$429 \cdot 4629.643958$ Commenced ascent of Arkeleenik river (Thelew dereth of Back)

$5 \quad 29 \cdot 70+29 \cdot 7 \cdot 2727-$

$629 \cdot 7329 \cdot 6544$ - Wind N.E., light; very fine.

$729.6029 \cdot 4840$ - Wind N.E., light. Ascending.$$
\text { 29.50 29.43 39 - Travelling west towards Great }
$$
Travelling west

$29 \cdot 4429 \cdot 4347 \quad 63$ Wind N.E.

$29 \cdot 4729 \cdot 4545 \quad-$ Wind N.E., showery.

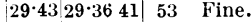

$29 \cdot 3029 \cdot 2337$ - Fine.

$29 \cdot 20 \cdot 29 \cdot 1637$ - Fine

$29 \cdot 2129 \cdot 2037$ - Fine.

$29 \cdot 2328 \cdot 9836$ - Hine.

$28.9328 .874 *$ - Altitude 777 feet.

28.8828 .8049 - Travelling west and ascending.

$28 \cdot 78 \cdot 28 \cdot 70$ \begin{tabular}{|l|l|l|l}
$28 \cdot 78$ & $28 \cdot 70$ & \\
$28 \cdot 82$ & $29 \cdot 08$ & 40 & -
\end{tabular} \begin{tabular}{ll|l|l|l|}
$28 \cdot 82$ & $29 \cdot 08$ & 40 \\
$29 \cdot 20$ & 28.81 & 30 & -
\end{tabular}

$28 \cdot 6628 \cdot 7632$ - Rain in morning.

$28 \cdot 8028 \cdot 57 \cdot 28$ -

$28 \cdot 4628 \cdot 28$ 28

$28 \cdot 3028 \cdot 17 \cdot 24$ - Altitude $13 \$ 4$ feet. The divide. $28 \cdot 2728 \cdot 2931$ - Skiff of snow.

$28 \cdot 34 \quad 28 \cdot 30 \quad 32$ -

$28 \cdot 2528 \cdot 2334$ - Wind N.W.

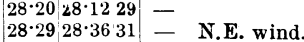

$28 \cdot 3728 \cdot 3734$ - Dull and showery in morning.

Fast end Clinton Colden lake.

$3128 \cdot 4828 \cdot 4333 \quad 43$ W N.W. wind. Still on Clinton Colden lake.

128.5528 .6228

228.6828 .6232 - Travelling west on Clinton Colden lake.

\begin{tabular}{l|l|l|l|l}
3 & 28 & 56 & 28 & 38 \\
35 & 47 & Strait between Clinton Colden
\end{tabular} and Aylmer lakes.

428.3728 .3030 - Returning south and east on

$6 \quad 28 \cdot 1628 \cdot 3231 \quad$ - Wind N.W. East eud of Clinton

Between Clinton Colden and

828.3228 .2033 - Altitude 1252 feet. On Artillery lake.

$928 \cdot 0628 \cdot 27 \quad 36 \quad 42$ N E. Moderate gale.

$10 \quad 28 \cdot 13 \mid 27 \cdot 97 \quad 34 \quad 43$ S.S.E. heavy wind.

1 Accident happened.

Thougl.t we saw smoke. Went to look. Tried to $13\{$ swim ; built raft and got canoe. Proceed $d$ down river, which we shortly afterwards had to leave. 


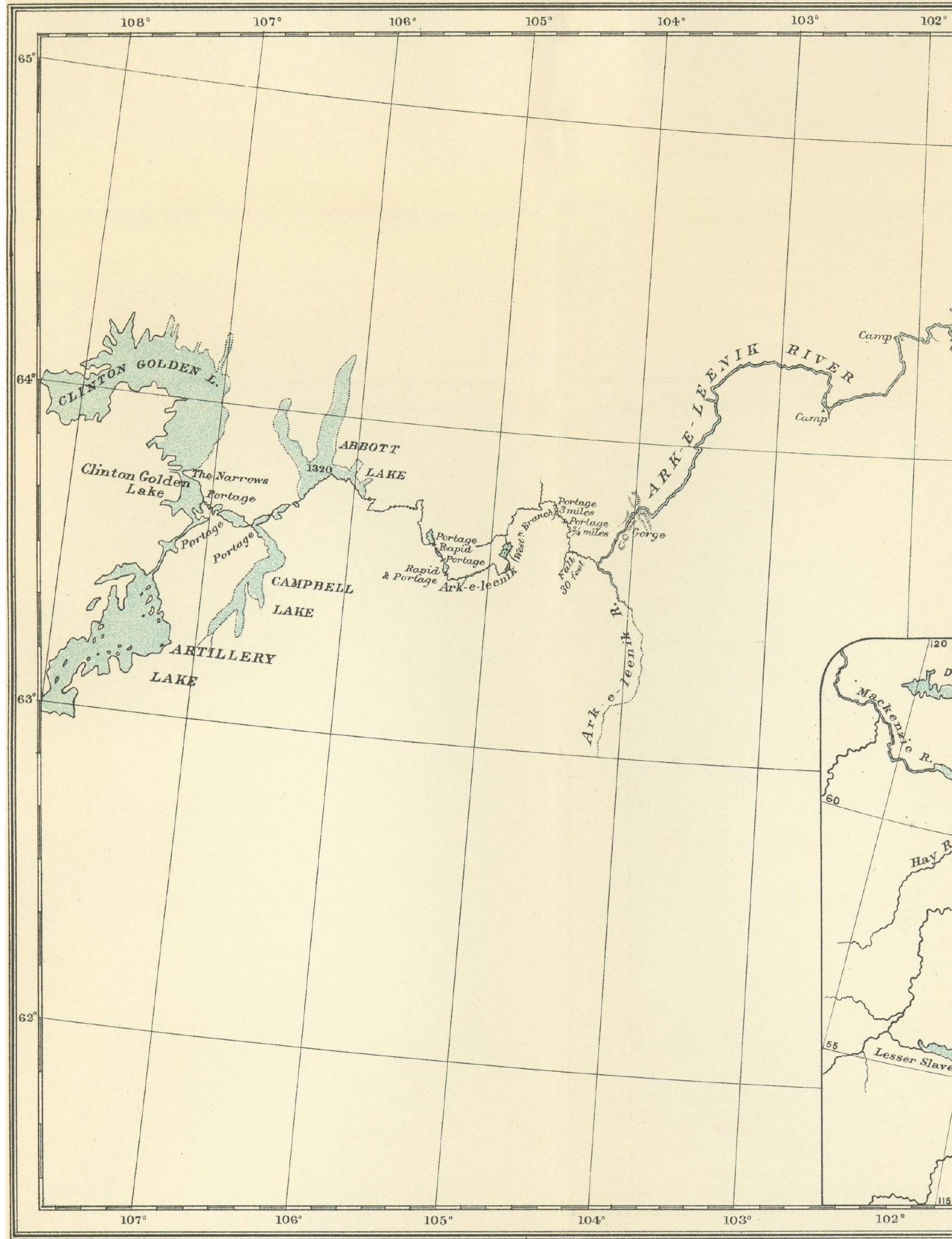




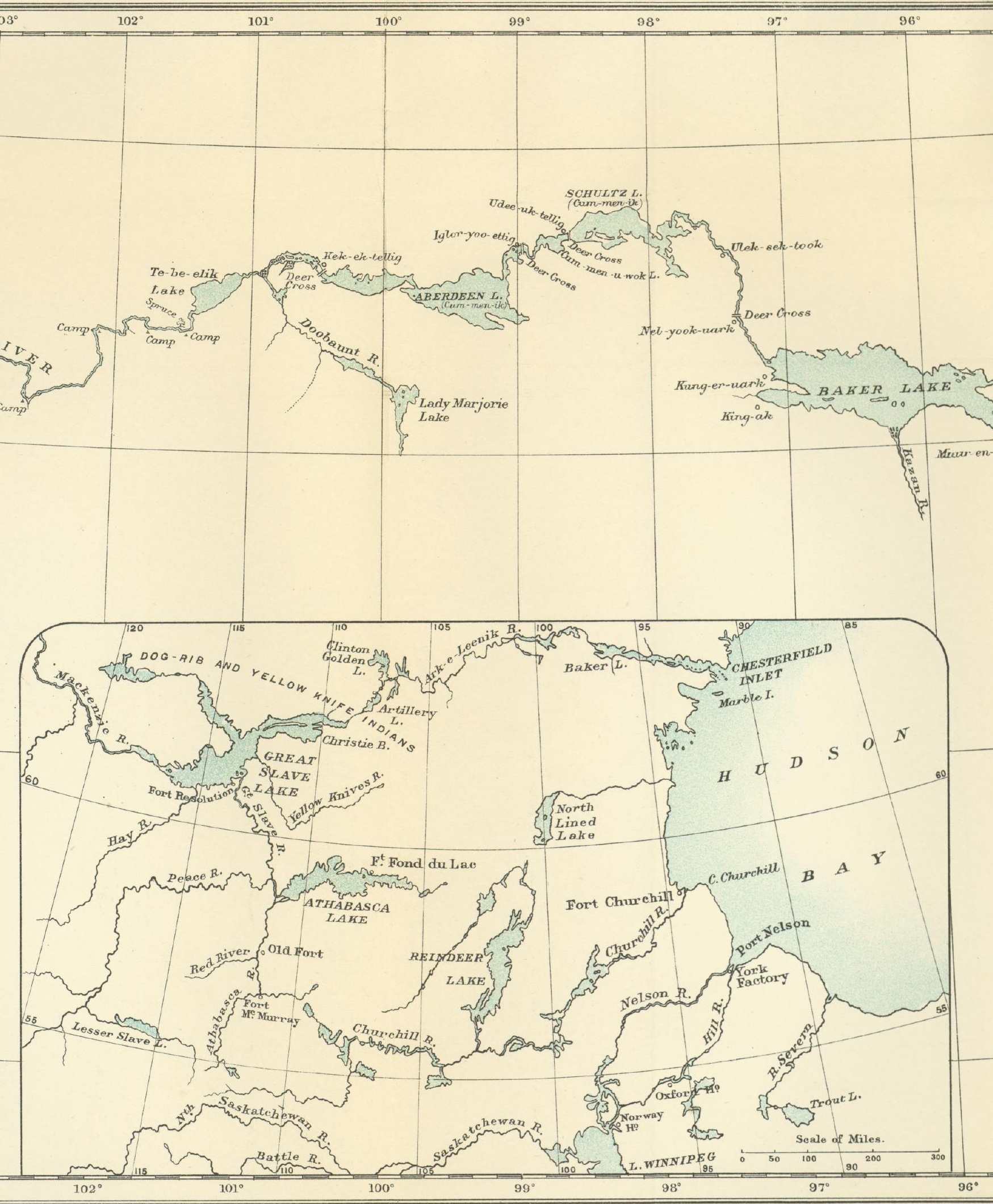

Published by the Royal Geographical Society. 
